DOI

\title{
РЕЗУЛЬТАТЫ МОДЕЛИРОВАНИЯ НАПРЯЖЕННО-ДЕФОРМИРОВАННОГО СОСТОЯНИЯ ГЛАЗА
}

\author{
М. Л. Кочина, И. В. Каплин, Н. М. Ковтун \\ Харьковская медицинская академия последипломного образования \\ THE RESULTS OF MODELING OF STRESS-DEFORMED STATE OF EYE

\section{Kharkiv Medical Academy}

Введение. Патология глазодвигательного аппарата, сопровождающаяся косоглазием, и нарушение бинокулярного зрения занимают значительный удельный вес в структуре заболеваний органа зрения у детей. Создание новых неинвазивных методов исследования и диагностики патологии глаза и зрительной системы, основанных на их физических свойствах, является актуальной задачей.

Результаты и их обсуждение. Большой теоретический и практический интерес представляют разработка и дальнейшее совершенствование объективных методов исследования глаза в поляризованном свете. Интерференционные картины, наблюдаемые на роговице в поляризованном свете, отражают распределение внутренних напряжений в оболочке живого глаза. Эти напряжения возникают под действием внутриглазного давления (ВГД) и глазодвигательных мышц (ГДМ) на оболочку глаза и отражают их состояние.

Для практического применения интерференционных картин глаз при диагностике структурнофункционального состояния ГДМ необходима разработка количественных критериев их оценки. Для этих целей нами были использованы модели напряженно-деформированного состояния (НДС) глаза.

Разработанные модели НДС глаза с использованием теории тонких оболочек и системы конечноэлементного анализа ANSYS позволяют рассчитать распределение внутренних напряжений в роговице глаза и определить геометрические характеристики интерференционных картин при разных видах патологии ГДМ, что служит инструментом для усовершенствования методов диагностики разных видов косоглазия при формировании тактики хирургического вмешательства. Совместное использование двух различных подходов к моделированию позволяет не только построить расчетные изохромы (линии равных напряжений), но и определить численные значения напряжений в каждой точке оболочки.

На основании асимптотических формул теории тонких оболочек нами были построены линии равных напряжений, совпадающие по форме с экспериментальными. Это позволило построить классификатор структурно-функционального состояния ГДМ по интерференционным картинам. Использование системы инженерного анализа ANSYS позволило определить численные значения внутренних напряжений в исследованных точках роговицы. Для расчета значений напряжений в оболочке глаза и построения линий равных напряжений была создана расчетная схема глаза, компьютерные модели поверхности роговицы и оболочки глаза. Для повышения точности расчетов были использованы реальные показатели, характеризующие упругие свойства оболочек и их геометрические параметры. Роговица и склера глаза моделировались конечными элементами SHELL 181. Оболочка глаза разбивалась на конечные элементы таким образом, чтобы обеспечить возможность перемещать точки приложения сил, соответствующих наружным прямым ГДМ.

Вывод. Полученные в результате моделирования результаты позволяют по форме интерференционных картин глаз судить о структурно-функциональном состоянии ГДМ в норме и при патологии. 